\title{
The Critical Role of Micro, Small \& Medium Enterprises in Employment Generation: An Indian Experience
}

\author{
Rajeevan N. ${ }^{1}$, Sulphey M. M. ${ }^{2}$ \& Rajasekar S. ${ }^{3}$ \\ ${ }^{1}$ Research Scholar, Anna University of Technology, Coimbatore, India \\ ${ }^{2}$ Dean (ARC), T. K. M Institute of Management, Kollam, India \\ ${ }^{3}$ Principal, Akshaya Institute of Management Studies, Coimbatore, India \\ Correspondence: Rajeevan N., Society for Entrepreneurship Management \& Research, T.C 4/2120 (1), Rejatham, \\ Pattom Kowdiar Road, Pattom Palace.PO, Trivandrum, Kerala-695 004, India. Tel: 91-471-231-9588; \\ 91-944-703-9290. E-mail: rajeevan1952@gmail.com
}

Received: June 8, 2015 Accepted: July 14, 2015 Online Published: August 18, 2015

doi:10.5539/ass.v11n24p258

URL: http://dx.doi.org/10.5539/ass.v11n24p258

\begin{abstract}
The purpose of this study is to examine the role of Micro, Small and Medium Enterprises (MSMEs) in Indian economy towards employment generation. It is found that this sector provides employment to nearly 60 million people through 26 million enterprises. In terms of employment generation, place of MSMEs is next to agriculture. Second All India census of Small Scale Industries (Financial Year 1987-88) had recorded 121.74 per cent growth in employment in this sector. Though the Third All India census of Small Scale Industries (Financial Year 2001-02) showed a decline in the growth of employment, this sector has achieved better growth in the fourth census (Financial Year 2006-07) as a reflection of the structural reforms implemented in the Indian economy. This study also reveals that the unregistered enterprises generate more than 80 per cent of the employments. By computing the Compound Annual Growth Rate (CAGR) in the MSMEs sector of India, it has seen that CAGR for the growth of employment in the post reform period is higher than the pre reform period. Even after the integration of Indian economy with global economy in 1991, MSMEs sector of India has performed well in employment generation.
\end{abstract}

Keywords: all India censuses of small scale industries, employment generation, micro small and medium enterprises

\section{Introduction}

Economic development of a nation is closely associated with the growth of its industrial sector. Industrial sector is composed of Large, Medium, Small and Micro enterprises. While large industries help the overall economic development of a nation, the contribution of Micro, Small and Medium Enterprises (MSMEs) is quite significant in employment generation, industrial production and exports. Small scale industries have the advantage of labour intensiveness, low cost technology, low investment and short gestation period (Singh, Rana, \& Singhal, 2009). The MSMEs sector is also known as Small and Medium Enterprises (SMEs) Sector (Nagayya \& Rao, 2011). Small and Medium enterprises play a key role in job creation, providing two thirds of all formal jobs in developing countries and up to 80 per cent in low income countries (Kok, Deijl, \&Van Essen, 2013). In developed nations also SMEs has to play a critical role in employment generation and overall growth of GDP. Small and Medium Enterprises have emerged as an engine of growth in the new Millennium (Prasad, 2004). In many countries as the economies develop, the share of agriculture to GDP began to decrease and it results in surplus labour force. In 1950-51, contribution of agriculture to India's GDP was 51.9 per cent. This declined to 13.7 per cent in 2012-13 (Ministry of Agriculture, Government of India, 2013). In the year 1951, more than 70 per cent of Indian population depended on agriculture for their livelihood and now it is nearly 50 per cent. It is quite relevant that SMEs in most of the nations including India provide employment to this surplus labour force from the agriculture sector. In Brazil 59 per cent of the employed population are in SMEs. In Japan 70 per cent of the wage earners work in SMEs (Small Industries Development Bank of India [SIDBI] Report on MSMEs Sector, 2010). In developed countries such as Germany, Italy, Greece, France and USA share of SMEs to total employment is 99 per cent (Bala, 2007). 
In India, MSMEs sector contributes nearly eight per cent of its GDP, 45 per cent of industrial output and 40 per cent of exports. The most significant factor in this respect is that the MSMEs sector provides employment to nearly 60 million persons through 26 million enterprises (Fourth All India Census of MSMEs, 2006). In terms of employment, it comes next to agriculture. Since independence, Government of India has been providing special priorities to this sector through various policies and programmes. Because of these, the number of enterprises and employments has increased by many folds. In 1950-51, number of enterprises was only 16 Thousands and employment was 700 Thousands. In the year, 2006 total number of MSMEs reached above 26.136 Millions and employment generated rose to nearly 60 Millions. Prior to the year 1991 growth of this sector was augmented through several protectionist policies. From 1991 onwards with the implementation of Globalization and Liberalization in Indian economy, the policies of promotion replaced these protectionist policies. These policies aim to enhance competitiveness of MSMEs sector in meeting the new challenges posed by liberalization and globalization.

There is no globally accepted definition for MSMEs. Different nations use different criteria for defining this sector. Investment ceiling and employment are the basis for most of these definitions. According to World Bank Research paper, 54 countries define SMEs as enterprises employing not more than 200-300 people (SIDBI Report on MSMEs Sector, 2010). In India, investment in plant and machinery is the basis used for defining this sector. As per the Micro, Small and Medium Enterprises Development (MSMED) Act of 2006, Micro Enterprise is one in which investment in plant and machinery does not exceed rupees 2.5 Millions. This limit is above 2.5 Millions and up to 50 Million rupees in Small Enterprises. Medium Enterprises have an investment above rupees 50 Millions but should not exceed 100 Millions. In the case of Service sector enterprises, investment in equipment up to rupees one Million is Micro and above one Million but not exceeding rupees 20 Millions are Small Enterprises. Medium Enterprises in the service sector have their investment above 20 Million rupees but do not exceed rupees 50 Millions.

\section{Review of Literature}

MSMEs sector is the second largest source of employment in India next to agriculture sector. This sector uses local resources and talents to create more jobs with less investment. Several researchers have analyzed the pivotal role of MSMEs in employment generation and overall development of economies.

The Study of Liedholm and Mead (1987) observe that third world governments recognize the contribution of MSMEs in the creation of jobs and poverty alleviation. According to Bharti (1978), small-scale industries create large-scale employment. United Nations Industrial Development Organization (UNIDO, 1968) emphasizes in its report that growth of SSIs will increase the production and employment in developed and developing economies. Unemployment is a serious problem in developing countries. Development of Small-scale industries can deal with the challenges of unemployment (Giri, 2004). Ayanda and Laraba (2011) studied the performance of SMEs in Nigerian economy. They observe that after the attainment of independence the government of Nigeria gives much importance to SMEs andthus the incidence of poverty and unemployment in Nigeria have reduced to an extent. Another researcher Kumar (2010) views Small Scale Industries as an engine of equitable economic growth and poverty alleviation. According to Tambunan (2009) SMEs in Asian developing countries such as India, China, Pakistan, Indonesia, Malaysia, Thailand, Vietnam and Bangladesh can solve the problems of unemployment and poverty. Arora and Gupta (2008) viewed that in post independent India small Scale industries created more employment in the economy and this sector is an engine for employment generation. Government of India recognized the prime role of MSMEs in employment generation and socio economic development of the country. So Central and State governments introduce and implement several programmes for its growth. Because of this concerted efforts, today MSMEs sector contributes more than 80 per cent of the total industrial units, 40 per cent of the industrial production, 35 per cent of the exports and nearly 80 per cent of the industrial employment in India (Narasaiah \& Murthy, 2009). According to Singh (2009), Small-scale industries act as catalysts in the socio- economic development of India. They facilitate in tapping the resources for judicious use of investment, in reducing regional disparities, generating employment opportunities, and increasing exports by fostering entrepreneurship.

\section{Objectives of the Study}

- To study the growth of employment in the SSIs/MSMEs Sector of India

- To make a comparison of the growth of employment in the SSIs/ MSMEs sector in Indian States and Union territories

- To compare employment generated in SSIs/ MSMEs Sector in the Pre-Reform and Post Reform periods 


\section{Methodology}

This study is an analytical and descriptive one and mainly depends on secondary data published by the Ministry of MSMEs Government of India, Results of the Economic survey, Results of various All India Censuses of SSIs/MSMEs, SIDBI Report on MSMEs Sector 2010, Annual Reports on SSIs/MSMEs sector etc. The statistical tool Percentage is used to analyze the data collected from these sources and thus assessed the growth trend of employment in the MSMEs Sector.

\section{Growth of Employment in the SSIs/MSMEs Sector of India}

Indian SSIs/MSMEs Sector is composed of both registered and unregistered enterprises. The enterprises registered in the District Industries Centres (DIC) of the respective States/Union Territories of India form the Registered Enterprises and others without a registration with the DICs are the Unregistered Enterprises. Planned development of Indian SSI sector begins with the declaration of the first Industrial Policy resolution of 1948. During the last six decades, this sector has grown as a major component of India's industrial sector in terms of production, export and employment generation. Since 1991 Micro and Small Industries sector in India has been undergone several reforms like replacing the 'Policy of protection by Policy of promotion' and it is in a transitional stage, i.e. from protection to promotion. This sector is now facing severe competition from Multi National Corporations (MNCs) as well as large Indian firms.

\subsection{Growth of Employment in the Registered SSIS/MSMEs Sector}

Government of India conducts All India Censuses of Small Scale Industries for assessing the growth of this sector and they help in framing future promotional policy packages that could activate growth of MSMEs. So far, four such censuses have conducted. The results of these four censuses are in Table 1.

Table 1. Growth of Employment in the Registered SSIs/MSMEs in India

\begin{tabular}{cccccc}
\hline Name of Census & $\begin{array}{c}\text { Number of } \\
\text { Enterprises (in } \\
\text { Thousands) }\end{array}$ & $\begin{array}{c}\text { Growth rate } \\
(\%)\end{array}$ & $\begin{array}{c}\text { Employment (in } \\
\text { Thousands) }\end{array}$ & $\begin{array}{c}\text { Growth rate } \\
(\%)\end{array}$ & $\begin{array}{c}\text { Employment } \\
\text { Generated per } \\
\text { Enterprises }\end{array}$ \\
\hline First census (1972-73) & 139.577 & --- & 1653.178 & --- & 11.84 \\
Second census (1987-88) & 582.368 & 317.23 & 3665.810 & 121.74 & 6.29 \\
Third census (2001-02) & 1374.974 & 136.10 & 6163.479 & 68.13 & 4.48 \\
Forth census (2006-07) & 1563.974 & 13.74 & 9309.486 & 51.04 & 5.95 \\
\hline
\end{tabular}

(Source: Compiled by the researcher using the data from the four Results of All India Census of SSIs/MSMEs published by Government of India.)

According to the first census (1972-73) there were 139.577 Thousands SSI units in the country which provided employment to 1653.178 Thousands persons. Results of the second census (1987-88) showed that the number of SSI units increased to 582.368 Thousands, with a phenomenal rise in employment generated to 3665.810 Thousands. Thus, there occurred a growth of 317.23 per cent in the number of units and 121.74 per cent in employment. The total number of registered units in the third census (2001-02) is 1374.974 Thousands and employment generated grew to 6163.479 Thousands. The latest census of MSMEs (Fourth All India Census) started after the enactment of MSMED Act of 2006 and completed by 2006-07. This Act redefined the sector as Micro, Small, and Medium Enterprises Sector by including service sector and medium scale units. The total number of registered enterprises as per this census is 1563.974 Thousands with an employment of 9309.486 Thousands.

As per the first and second census results, average employment generated by an SSI unit is 11.84 and 6.29 respectively. The third census showed that the growth of registered units decreased from 317.23 per cent of second census to 136.10 per cent. During this period, the growth of employment also decreased to 68.13 per cent from 121.74 of the previous census. Employment generated per enterprises also decreased from 6.29 of second census to 4.48 in the third census. However, in the fourth census, the number of registered enterprises increased by 13.74 per cent. Employment generated has shown a growth of 51.04 per cent. The employment generated by an enterprise increased to 5.95 as against 4.48 of the third census. The above analysis makes it clear that despite the increased competitions from the large Indian industries the MSMEs sector of India achieved substantial progress in the field of employment generation. 


\subsection{Growth of Employment in the Unregistered SSIS/MSMEs Sector}

The First and Second All India Census of SSIs covered only industrial units registered with the District Industries Centres. From the third census onwards, the unregistered units too included in the data collection processes. Table 2 depicts the growth of employment in the unregistered sector.

Table 2. Growth of Employment in the Unregistered SSIs/MSMEs in India

\begin{tabular}{|c|c|c|c|c|c|c|c|}
\hline \multirow[t]{2}{*}{ Name of Census } & \multicolumn{2}{|c|}{$\begin{array}{c}\text { Number of Enterprises (in } \\
\text { Thousands) }\end{array}$} & \multirow[t]{2}{*}{$\begin{array}{l}\text { Growth } \\
\text { rate }(\%)\end{array}$} & \multicolumn{2}{|c|}{$\begin{array}{l}\text { Employment (in } \\
\text { Thousands) }\end{array}$} & \multirow[t]{2}{*}{$\begin{array}{l}\text { Growth } \\
\text { rate }(\%)\end{array}$} & \multirow[t]{2}{*}{$\begin{array}{l}\text { Employment } \\
\text { per Enterprises }\end{array}$} \\
\hline & Total & Unregd. & & Total & Unregd. & & \\
\hline $\begin{array}{l}3^{\text {rd }} \text { census } \\
(2001-02)\end{array}$ & 10521.190 & $\begin{array}{l}9146.216 \\
(86.93 \%)\end{array}$ & --- & 24932.763 & $\begin{array}{l}18769.284 \\
(75.28 \%)\end{array}$ & --- & 2.05 \\
\hline $\begin{array}{l}4^{\text {th }} \text { census } \\
(2006-07)\end{array}$ & 26136.424 & $\begin{array}{c}24572.450 \\
(94.02 \%)\end{array}$ & 168.66 & 59566.525 & $\begin{array}{c}50257.039 \\
(84.37 \%)\end{array}$ & 167.76 & 2.04 \\
\hline
\end{tabular}

(Source: Compiled by the researcher using the data from the Third and Fourth All India Census Of SSIs/MSMEs)

According to Third census the total number of SSI enterprise is 10521.190 Thousands and employment generated is 24932.763 Thousands. Among these, 9146.216 Thousands are in the unregistered sector. They provided employment to 18769.284 Thousands persons. This means that 86.93 percent enterprises are unregistered ones and employments generated by them are 75.28 per cent. During the Fourth census, the total number of MSMEs increased to 26136.424 Thousands, of which 94.02 per cent ( 24572.450 Thousands) are unregistered enterprises. Total employments generated in MSMEs sector is 59566.525 Thousands, where the contribution of unregistered sector reaches 84.37 per cent (50 257.039 Thousands). A comparison of the third and fourth census shows that the growth rate in the number of unregistered MSMEs and employment generated by them are 168.66 and 167.76 per cent respectively.

The fourth census reveals that the unregistered MSMEs sector has achieved higher growth in terms of enterprises and employment than the registered sector. However, employment provided per unregistered unit remained more or less same in both these two censuses. This massive increase in number of enterprises and employments in the Fourth census is largely due to the inclusion of service sector and medium scale industrial units into the MSMEs sector.

\section{Growth of Employment in the States \& Union territories}

In a developing country like India where unemployment and underemployment are big problems, the Small Scale Enterprises play a significant role in employment generation.All the four censuses of SSIs/MSMEs emphasized this.

\subsection{Growth of Employment in the Registered SSIs/MSMEs in States}

Growth of employment in the 28 states of India in the registered SSIs/MSMEs sector shows much variation among states. Table 3 illustrates this.

According to the first census total employment generated in theSSI sector at the national level is 1653.178 thousands. More than 90 per cent of this employment has concentrated in fifteen states. These states are. Uttar Pradesh, Maharashtra, West Bengal, Tamil Nadu, Andhra Pradesh, Karnataka, Kerala, Rajasthan, Madhya Pradesh, Odisha, Bihar, Gujarat, Punjab, Assam and Haryana. In the second census, all the states other than Maharashtra, West Bengal, Kerala, Punjab and Assam the employment figures showed a growth rate of over 100 per cent. While Mizoram (11630.50) had the highest growth rate and Kerala (33.82) had the lowest position. In the Third census, 21 states showed a declining trend in growth rate of employment. Negative growth was recorded in states such as West Bengal, Bihar, Goa, Arunachal Pradesh, Mizoram and Sikkim. However in the fourth census there is considerable improvement in the growth rate of employment in 15 states. These include the states of Maharashtra, West Bengal, Rajasthan, Odisha, Bihar, Gujarat, Assam, J\&K, Himachal Pradesh, Tripura, Goa, Nagaland, Arunachal Pradesh, Mizoram and Sikkim. Negative growth of employment was noticed only in Chhattisgarh and Andhra Pradesh. It is noteworthy that the states of Maharashtra and Assam showed considerably upward growth of employment in all the four censes. From the above analysis, it is revealed that 
the structural changes implemented in the Indian economy since 1991 had a favourable impact in the growth of employment in this sector in most of the states.

Table 3. Growth of Employment in the SSIs/MSMEs in States in the registered sector (in thousands)

\begin{tabular}{|c|c|c|c|c|c|c|c|}
\hline $\begin{array}{l}\text { Sl. } \\
\text { No } \\
\text { Name } \\
\text { states }\end{array}$ & $\begin{array}{l}1^{\text {st }} \text { census } \\
(1972-73)\end{array}$ & $\begin{array}{c}2^{\text {nd }} \text { census } \\
(1987-88)\end{array}$ & $\begin{array}{l}\text { Growth } \\
\text { rate } \\
(\%)\end{array}$ & $\begin{array}{r}3^{\text {rd }} \text { census } \\
(2001-02) \\
(\%\end{array}$ & $\begin{array}{l}\text { Growth } \\
\text { rate } \\
\text { b) }\end{array}$ & $\begin{array}{l}4^{\text {th }} \text { census } \\
(2006-07)\end{array}$ & $\begin{array}{l}\text { Growth } \\
\text { rate } \\
(\%)\end{array}$ \\
\hline 1 Uttar Pradesh & 160.027 & 348.908 & 118.03 & 581.810 & 66.75 & 754.908 & 29.75 \\
\hline 2 Maharashtra & 239.775 & 355.900 & 48.43 & 630.576 & 77.17 & 1088.790 & 72.67 \\
\hline 3 West Bengal & 176.198 & 311.838 & 76.98 & 254.809 & -18.29 & 360.255 & 41.38 \\
\hline 4 Tamil Nadu & 215.182 & 536.381 & 149.27 & 882.083 & 64.45 & 1426.056 & 61.67 \\
\hline 5 Andhra Pradesh & 78.763 & 276.127 & 250.57 & 383.335 & 38.82 & 382.977 & -0.09 \\
\hline 6 Karnataka & 64.385 & 244.039 & 279.03 & 477.284 & 95.57 & 789.359 & 65.38 \\
\hline 7 Kerala & 126.514 & 169.309 & 33.82 & 540.260 & 219.09 & 621.423 & 15.02 \\
\hline 8 Rajasthan & 45.860 & 122.550 & 167.22 & 199.676 & 62.93 & 341.690 & 71.12 \\
\hline 9 Madhya Pradesh & 59.612 & 158.808 & 166.40 & 249.476 & 57.09 & 298.047 & 19.47 \\
\hline 10 Odisha & 18.614 & 69.305 & 272.33 & 80.888 & 16.71 & 173.088 & 113.98 \\
\hline 11 Bihar & 61.465 & 181.781 & 195.75 & 136.914 & -24.68 & 147.775 & 7.93 \\
\hline 12 Gujarat & 114.500 & 276.955 & 141.88 & 578.764 & 108.97 & 1244.981 & 115.11 \\
\hline 13 Punjab & 123.544 & 206.209 & 66.91 & 337.443 & 63.64 & 415.838 & 25.23 \\
\hline 14 Assam & 19.652 & 34.475 & 75.43 & 64.623 & 87.44 & 210.507 & 225.74 \\
\hline 15 Haryana & 45.803 & 105.656 & 130.67 & 241.171 & 128.26 & 381.774 & 58.30 \\
\hline 16 Jharkhand & * & * & - - & 71.071 & -- & 75.134 & 5.72 \\
\hline 17 Chhattisgarh & ** & ** & -- & 91.000 & -- & 75.094 & -17.48 \\
\hline 18 Jammu \& Kashmir & 9.598 & 40.658 & 323.61 & 50.707 & 24.71 & 90.158 & 77.80 \\
\hline 19 Uttarakhand & $* * *$ & *** & -- & 40.583 & -- & 79.941 & 95.68 \\
\hline 20 Himachal Pradesh & 5.851 & 25.536 & 336.43 & 37.760 & 47.86 & 65.148 & 72.53 \\
\hline 21 Tripura & 1.698 & 10.069 & 492.99 & 11.666 & 15.86 & 23.166 & 98.5 \\
\hline 22 Manipur & 3.409 & 10.216 & 196.68 & 19.626 & 92.11 & 19.960 & 1.70 \\
\hline 23 Goa & 7.253 & 19.935 & 174.85 & 16.664 & -16.40 & 33.330 & 100.01 \\
\hline 24 Meghalaya & 1.188 & 3.780 & 218.18 & 10.734 & 183.96 & 12.701 & 18.3 \\
\hline 25 Nagaland & 0.448 & 3.059 & 582.81 & 4.967 & 62.37 & 16.281 & 227.78 \\
\hline 26 Arunachal Pradesh & 0.181 & 2.771 & 1430.93 & 1.481 & -46.55 & 5.411 & 265.36 \\
\hline 27Mizoram & 0.036 & 42.233 & 117213.90 & 9.061 & -78.54 & 26.032 & 187.30 \\
\hline 28 Sikkim & available & 1.033 & --- & 0.959 & -7.16 & 1.159 & 20.85 \\
\hline
\end{tabular}

(Source: - SIDBI Report on MSME Sector 2010; Final Result of $4^{\text {th }}$ Census of MSMEs 2012)

*Part of Bihar, ** Part of MP, *** Part of UP

\subsection{Growth of Employment in the Unregistered SSIs/MSMEs in States}

Unregistered enterprises constitute a major component in the MSMEs sector. Third All India census for SSIs (Financial Year 2001-02) included data related to the units in the unregistered sector for the first time. Fourth All India census of MSMEs too included the unregistered enterprises. State wise growth of employment in the unregistered sector is presented in Table 4.

Third census estimated that in the unregistered sector there are 9 146. 216 thousands enterprises in the country and they provided employment to 18769.284 thousands persons. The number of enterprises in the Fourth census (FY 2006-07) is 24572.450 thousands with an employment of 50257.039 thousands. The Fourth census has recorded 167.76 per cent growth of employment in the unregistered sector at the national level (Table 2). Among the 28 states of India, 14 states have achieved a higher growth rate than the national level in employment generation in the unregistered sector. The state of Sikkim attained the highest growth rate of 6474.93 per cent. Even though the states of Manipur and Mizoram have negative growth rate of employment in the unregistered sector, in the registered sector they show positive growth. An interesting factor noticed is that 24 states showed a higher growth rate in employment in the unregistered sector, than the employment generated in registered units in these states. The states of Andhra Pradesh and Chhattisgarh that had negative growth of employment in the 
registered sector achieved positive growth rate in the unregistered sector. According to the Fourth census Andhra Pradesh turned out to be the highest provider of employment in the unregistered sector ( 5754.068 thousands) followed by the states of West Bengal (5 466.337 thousands) and Maharashtra (5 370.908 thousands). It can be seen that the employment generated in the unregistered units in the North-East states of Manipur, Nagaland and Mizoram are very poor.

Table 4. Growth of employment in the unregistered SSIs/MSMEs in States (in Thousands)

\begin{tabular}{|c|c|c|c|c|}
\hline $\begin{array}{l}\text { Sl. } \\
\text { No. }\end{array}$ & Name of State & $\begin{array}{r}3^{\text {rd }} \text { Census } \\
(2001-2002)\end{array}$ & $\begin{array}{l}4^{\text {th }} \text { Census } \\
(2006-2007)\end{array}$ & $\begin{array}{l}\text { Growth rate } \\
(\%)\end{array}$ \\
\hline 1 & Uttar Pradesh & \multicolumn{2}{|c|}{3420.5645014 .36346 .59} & \\
\hline 2 & Maharashtra & 1420.924 & 5370.908 & 277.98 \\
\hline 3 & West Bengal & 1914.296 & 5466.337 & 185.55 \\
\hline 4 & Tamil Nadu & 1136.054 & 4794.581 & 322.03 \\
\hline 5 & Andhra Pradesh & 175.642 & 5754.068 & 3176.02 \\
\hline 6 & Karnataka & 1161.419 & 2895.439 & 149.30 \\
\hline 7 & Kerala & 574.401 & 2401.184 & 318.03 \\
\hline 8 & Rajasthan & 667.932 & 2066.855 & 209.44 \\
\hline 9 & Madhya Pradesh & 1095.117 & 2294.540 & 109.52 \\
\hline 10 & Odisha & 842.288 & 1755.087 & 108.37 \\
\hline 11 & Bihar & 945.771 & 1477.621 & 56.23 \\
\hline 12 & Gujarat & 687.912 & 1815.918 & 163.27 \\
\hline 13 & Punjab & 571.133 & 1290.650 & 125.98 \\
\hline 14 & Assam & 364.380 & 1100.795 & 202.10 \\
\hline 15 & Haryana & 312.288 & 971.848 & 211.20 \\
\hline 16 & Jharkhand & 204.999 & 637.065 & 210.76 \\
\hline 17 & Chhattisgarh & 440.766 & 652.802 & 48.10 \\
\hline 18 & $\mathrm{~J} \& \mathrm{~K}$ & 101.992 & 328.441 & 220.02 \\
\hline 19 & Uttarakhand & 154.480 & 317.115 & 105.27 \\
\hline 20 & Himachal Pradesh & 92.510 & 242.134 & 163.73 \\
\hline 21 & Tripura & 45.296 & 146.879 & 224.26 \\
\hline 22 & Manipur & 117.185 & 100.229 & -14.46 \\
\hline 23 & Goa & 12.647 & 99.874 & 689.70 \\
\hline 24 & Meghalaya & 54.852 & 89.589 & 63.32 \\
\hline 25 & Nagaland & 51.828 & 53.836 & 3.87 \\
\hline 26 & Arunachal & 2.206 & 35.698 & 1518.22 \\
\hline 27 & Mizoram & 15.789 & 11.624 & -26.37 \\
\hline 28 & Sikkim & 0.363 & 23.867 & 6474.93 \\
\hline
\end{tabular}

(Source: - SIDBI Report on MSME Sector 2010)

\subsection{Growth of Employment in the Registered SSIS/MSMEs in Union Territories}

In addition to the 28 states, India has seven Union Territories also. These union territories are directly administered by the central government.

The First census of SSIs collected data from four union territories only. They were Delhi, Puducherry, Chandigarh and Dadra \& Nagar Haveli. As per this census, the highest number of employment was produced in Delhi and lowest in Dadra \& Nagar Haveli. In the second census, two more union territories such as Andaman \& Nicobar Islands and Daman \& Diu were included. Here Dadra \& Nagar Haveli recorded the highest (455.11\%) growth rate of employment and Delhi the lowest with 87.99 per cent. Third and Fourth census covered all the seven Union territories. According to the Third census, highest growth rate of 1958.79 per cent was seen in Daman and Diu followed by Dadra and Nagar Haveli (519.78 per cent) and Puducherry (126.33 per cent). Delhi 
and Chandigarh showed negative growth. Fourth census records highest growth rate of employment (115.61 per cent) in Andaman and Nicobar Islands. This Union Territory, which was included only in the second census onwards, has an increasing trend in employment both in third and fourth census. In the Fourth census too Delhi depicts a negative growth. Lakshadweep is the other Union Territory which has a negative growth rate of employment in this Census.

Table 5. Employment generation in registered SSIs/MSMEs in Union Territories (in Thousands)

\begin{tabular}{|c|c|c|c|c|c|c|c|c|}
\hline $\begin{array}{l}\text { Sl. } \\
\text { No }\end{array}$ & $\begin{array}{l}\text { Name of } \\
\text { Union } \\
\text { Territory }\end{array}$ & $\begin{array}{l}1^{\text {st }} \text { census } \\
(1972-73)\end{array}$ & $\begin{array}{l}2^{\text {nd }} \text { census } \\
(1987-88)\end{array}$ & $\begin{array}{c}\text { Growth rate } \\
(\%)\end{array}$ & $\begin{array}{l}3^{\text {rd }} \text { census } \\
(2001-02)\end{array}$ & $\begin{array}{c}\text { Growth rate } \\
(\%)\end{array}$ & $\begin{array}{l}4^{\text {th }} \text { census } \\
(2006-07)\end{array}$ & $\begin{array}{c}\text { Growth rate } \\
(\%)\end{array}$ \\
\hline 1 & Delhi & 64.880 & 121.972 & 87.99 & 86.479 & -29.09 & 58.123 & -32.78 \\
\hline 2 & Puducherry & 2.570 & 8.721 & 239.33 & 19.739 & 126.33 & 21.086 & 6.82 \\
\hline 3 & Chandigarh & 2.882 & 10.579 & 267.07 & 10.563 & -0.15 & 11.705 & 10.81 \\
\hline 4 & $\begin{array}{c}\text { Andaman \& } \\
\text { Nicobar }\end{array}$ & NA & 1.672 & -- & 2.594 & 55.14 & 5.593 & 115.61 \\
\hline 5 & Daman \& Diu & NA & 1.233 & -- & 25.385 & 1958.79 & 25.518 & 0.52 \\
\hline 6 & $\begin{array}{c}\text { Dadra \& } \\
\text { Nagar Haveli }\end{array}$ & 0.381 & 2.115 & 455.11 & 12.918 & 519.78 & 26.476 & 104.95 \\
\hline 7 & Lakshadweep & NA & NA & -- & 0.253 & -- & 0.002 & -99.20 \\
\hline
\end{tabular}

(Source: - SIDBI Report on MSME Sector 2010; Final Result of $4^{\text {th }}$ Census of MSMEs 2012)

\subsection{Growth of Employment in the Unregistered SSIS/MSMES in Union Territories}

Growth of employment in the unregistered SSIs/MSME in the union territories is presented in Table 6

Table 6. Employment generation in unregistered SSIs/MSMEs in Union Territories (in Thousands)

\begin{tabular}{|c|c|c|c|c|}
\hline $\begin{array}{l}\text { Sl. } \\
\text { No }\end{array}$ & $\begin{array}{l}\text { Name of Union } \\
\text { Territory }\end{array}$ & $\begin{array}{l}3^{\text {rd }} \text { census } \\
(2001-02)\end{array}$ & $\begin{array}{c}4^{\text {th }} \text { census } \\
(2006-07)\end{array}$ & $\begin{array}{c}\text { Growth rate } \\
(\%)\end{array}$ \\
\hline 1 & Delhi & 466.920 & 2800.294 & 499.73 \\
\hline 2 & Puducherry & 15.470 & 50.471 & 226.25 \\
\hline 3 & Chandigarh & 37.689 & 82.760 & 119.58 \\
\hline 4 & Andaman \& Nicobar & 4.885 & 6.445 & 31.93 \\
\hline 5 & Daman \& Diu & & 50.770 & --- \\
\hline 6 & $\overline{\text { Dadra \& Nagar Haveli }}$ & 3.709 & 54.712 & --- \\
\hline 7 & Lakshadweep & Not available & 2.239 & --- \\
\hline
\end{tabular}

(Source: - SIDBI Report on MSME Sector 2010)

According to the latest MSMEs census, Delhi is in the first place with 2800.294 thousands employment in unregistered enterprises and Lakshadweep is in the last place with 2.239 thousands. In the Third census, data related to employment in unregistered enterprises in Daman \& Diu and Dadra \& Nagar Haveli are clubbed together, and Lakshadweep is not available. But in the Fourth census, data on all the seven Union Territories are separately available. Highest growth rate of employment (499.73per cent) has recorded in Delhi and the lowest in Andaman \& Nicobar (31.93 per cent). Puducherry and Chandigarh have growth rate above 100 per cent. It can be understood from the results of the Fourth census that the unregistered enterprises in Union Territories achieved better progress in employment generation.

\section{Growth of Employment in MSMEs in the Pre-Reform and Post-Reform Periods}

Post-reform period began in India by the introduction of globalization, liberalization and privatization policies in 
the year 1991. Since 1991, a series of economic reforms have been introduced in the Indian economy. India's agreement with World Trade Organization in 1995, dilutions in Monopolies and Restrictive Trade Practices (MRTP) Act and licensing policies, reduction in the items exclusively reserved for the SSIs etc created intense competition from large firms and multinational companies to the Indian MSMEs. However, in spite of all these constraints MSMEs have achieved better growth rate in terms of numbers of enterprises and employment in the post-liberalized period. For a comparative study of the growth of employment in the SSIs/ MSMEs sector, data related to employment generated for the period 1973-74 to 2011-12 are used. It is presented in Table 7.

Table7. Employment Generation in SSIs/MSMEs (Pre-Reform and Post Reform Period)

\begin{tabular}{lccccc}
\hline Pre-Reform & Employment & $\begin{array}{c}\text { Growth } \\
\text { Rate (\%) }\end{array}$ & Year & $\begin{array}{c}\text { Post-Reform } \\
\text { Employment } \\
\text { (Thousands) }\end{array}$ & $\begin{array}{c}\text { Growth } \\
\text { Rate (\%) }\end{array}$ \\
\hline $1973-74$ & 3970 & & $1990-91$ & 12530 & \\
$1974-75$ & 4040 & 1.76 & $1991-92$ & 16600 & 35.48 \\
$1975-76$ & 4590 & 13.61 & $1992-93$ & 17484 & 5.32 \\
$1976-77$ & 4980 & 8.49 & $1993-94$ & 18264 & 4.46 \\
$1977-78$ & 5400 & 8.43 & $1994-95$ & 19140 & 4.80 \\
$1978-79$ & 6380 & 18.14 & $1995-96$ & 19763 & 3.41 \\
$1979-80$ & 6700 & 5.01 & $1996-97$ & 20586 & 4.00 \\
$1980-81$ & 7100 & 5.97 & $1997-98$ & 21366 & 3.79 \\
$1981-82$ & 7500 & 5.63 & $1998-99$ & 22055 & 3.22 \\
$1982-83$ & 7900 & 5.33 & $1999-2000$ & 22910 & 3.87 \\
$1983-84$ & 8415 & 6.51 & $2000-01$ & 23873 & 4.20 \\
$1984-85$ & 9000 & 6.95 & $2001-02$ & 24933 & 4.44 \\
$1985-86$ & 9600 & 6.66 & $2002-03$ & 26021 & 4.36 \\
$1986-87$ & 10140 & 5.62 & $2003-04$ & 27642 & 4.30 \\
$1987-88$ & 10700 & 5.52 & $2004-05$ & 28257 & 4.10 \\
$1988-89$ & 11300 & 5.60 & $2005-06$ & 29491 & 4.36 \\
$1989-90$ & 11960 & 5.84 & $2006-07$ & 80523 & 173.04 \\
CAGR Pre & & & $2007-08$ & 84223 & 4.59 \\
reform & & $\mathbf{6 . 7 0}$ & $2008-09$ & 88114 & 4.41 \\
CAGR Post & & & $2009-10$ & 92219 & 4.61 \\
reform & & $\mathbf{9 . 9 6}$ & $2010-11$ & 96569 & 4.66 \\
Overall CAGR & & $\mathbf{8 . 6 6}$ & $2011-12$ & 101259 & 4.85 \\
\hline
\end{tabular}

(Source: Laghu Udyog Samachar Vol. XXIX.No.12 to 2, MSME Annual Report2010-11,2011-12, 2012-13)

In the pre reform period, the year 1974-75 recorded the lowest growth of employment (1.76\%) and the year 1978-79 had the highest growth of 18.14 per cent. In the post reform period highest growth of 173.04 per cent occurred in the year 2006-07. This sudden increase in employment in the post reform period is largely due to the enactment of the Micro Small and Medium Enterprises Development (MSMED) Act 2006, by which Medium scale and Service Enterprises are included in to the Small Scale Industries Sector (SSIs). By this Act the SSIs sector is redefined as Micro Small and Medium Enterprises (MSMEs) Sector. The above table shows that the SSIs/MSMEs compound annual growth (CAGR) of employment in the pre reform period is 6.70 per cent but it is 9.96 per cent in the post reform period. The statistical tool Independent Samples t Test also is applied to verify whether there is any difference in mean of employment generation in pre and post reform periods and it is found that even at 99 percent confidence level there is significant difference. It means that employment generated in SSIs/MSMEs sector increased in the post reform period. The combined CAGR of pre and post reform period is 8.66 per cent. It can be concluded that both in the pre and post-reform periods SSIs/MSMEs sector of India played a pivotal role in creation of new employment avenues.

\section{Relationship between Number of Enterprises and Employment Generated}

Correlation coefficient is calculated to study the relationship between the variables- the number of enterprises and the number of employment generated. It is given in Table 8. 
Table 8. Relationship between number of enterprises and employment generated

\begin{tabular}{|c|c|c|c|c|}
\hline Period & $\begin{array}{l}\text { Number of } \\
\text { Registered } \\
\text { Enterprises } \\
\text { (in Thousands) }\end{array}$ & $\begin{array}{l}\text { Number of } \\
\text { Employment } \\
\text { (in Thousands) }\end{array}$ & $\begin{array}{l}\text { Number of } \\
\text { Unregistered } \\
\text { Enterprises } \\
\text { (in Thousands) }\end{array}$ & $\begin{array}{r}\text { Number of } \\
\text { Employment } \\
\text { (in Thousands) }\end{array}$ \\
\hline $\begin{array}{l}\text { First Census } \\
(1972-73)\end{array}$ & 139.577 & 1653.178 & ---- & ---- \\
\hline $\begin{array}{l}\text { Second Census } \\
(1987-88)\end{array}$ & 582.368 & 3665.810 & --- & ---- \\
\hline $\begin{array}{l}\text { Third Census } \\
(2001-02)\end{array}$ & 1374.974 & 6163.479 & 9146.216 & 18769.284 \\
\hline $\begin{array}{l}\text { Fourth Census } \\
(2006-07)\end{array}$ & 1563.974 & 9309.486 & 24572.450 & 50257.039 \\
\hline $\left.\begin{array}{c}\text { Correlation } \\
\text { Coefficient }\end{array}\right\}$ & 0.960013672 & & 1.0000 & \\
\hline $\begin{array}{l}\text { Coefficient of } \\
\text { Determination }\end{array}$ & 0.921626251 & & 1 & \\
\hline
\end{tabular}

(Source: Compiled by the researcher using the data from the four Results of All India Census of SSIs/MSMEs published by Government of India)

Correlation coefficient in the registered sector is 0.96 and strong positive correlation is seen between the variables. The coefficient of determination is 0.92 . It indicates that 92 percent of the growth in employment is due to growth in the number of enterprises. In the unregistered sector there is perfect correlation between the two variables.

\section{Findings}

After attaining independence in 1947 India has been promoting the growth of SMEs through various policies and programmes. As a result of these the number of enterprises and employment in the SSIs/MSMEs sector of India increased manifold. Now this sector with above 26 million enterprises provides employment to nearly 60 million persons. In the Second All India Census of SSIs the growth rate of registered units was 317.23 per cent and that of employment was 121.74 per cent. Third census showed a decline in the growth rate of registered units and employment to 136.10 per cent and 68.13 per cent respectively. In the Fourth census the growth rate of enterprises in the registered sector is only 13.74 per cent but the growth of employment is 51.04 per cent.

Unregistered enterprises form a major segment of the SSIs/MSMEs sector of India. The fourth census shows that 94.02 per cent of the total enterprises and 84.37 per cent employments generated are in this sector. In the post reform period this sector has achieved higher growth rate in enterprises and employment than the registered sector. The fourth census gives the growth rate of unregistered enterprises as 168.66 per cent and that of employment being 167.76 per cent. This means that the unregistered sector has achieved better growth in enterprises and employment than the registered sector. In the unregistered sector all Indian states except Manipur and Mizoram have achieved better growth in employment than in the registered segment.

The fourth census reflected the impact of structural changes implemented in India since 1991. Compounded Average Growth Rate (CAGR) of employment in the post reform period is higher than the pre reform period. Independent sample $t$ test too shows that there is significant difference in mean of employment generated in both these periods. Hence it can be inferred that the MSMEs sector of India performed well in generating employment even after the implementation of globalization and liberalization policies.

\section{Conclusion}

In a developing country like India MSMEs sector can play a crucial role in creating employment avenues to the unemployed and underemployed people. More than 80 percent of the employment generated in this sector is contributed by unregistered enterprises. This emphasizes the need for giving priority to unregistered sector in future policies and plans for the promotion of MSMEs. It is also seen that despite the withdrawal of various protectionist policies and severe competition from Multi National Corporations and large Indian firms, MSMEs sector of India has achieved better progress in employment generation. Thus, it can be concluded that other developing nations of the world can also adopt the strategy of promoting MSMEs for employment generation and reducing unemployment 


\section{References}

Arora, S., \& Gupta, S. (2008). Small scale sector in India: An Engine for employment generation. In T. Sabanna (Ed.), Reforms and economic development in India (pp. 128-137). New Delhi: Serials Publications.

Ayanda, A. M., \& Laraba, A. S. (2011). Small and medium scale enterprises as a survival strategy for employment generation in Nigeria. Journal of Sustainable Development, 4(1), 200-206. http://dx.doi.org/10.5539/jsd.v4n1p200

Bala, N. (2007). Economic Reforms and Growth of Small Scale Industries. New Delhi: Deep \& Deep publishers.

Bharti, R. K. (1978). Industrial estates in developing economies. New Delhi: National Publishing House.

Giri, V. V. (2004). 50 years of SIDO. Laghu Udyog Samachar, 28-29(12), 19-20.

Kok, J. D., Deijl, C., \& Van Essen, C. V. (2013). Is small is still beautiful?: Literature review of recent empiricalevidence on the contribution of SMEs to employment creation. Berlin, Germany: German Ministry for Economic Cooperation and Development.

Kumar, N. P. (2010). Structure and performance of small scale industries in India. Productivity, 51(1), 69-90.

Leidholm, C., \& Mead, D. C. (1987). Small scale industries in developing countries: Empirical evidence and policy implications. MSU International Development Papers, No. 9. Retrieved from http://fsg.afre.msu.edu/papers/older/idp9.pdf

Ministry of Agriculture, Government of India. (2013). Pocket book on agricultural statistics 2013. New Delhi: Directorate of Economics \& Statistics.

Ministry of Micro, Small \&Medium Enterprises (MSMEs), Government of India. (2011). Annual Report2010-11. New Delhi: Development commissioner.

Ministry of MSME, Government of India. (2011). Final Report: Fourth All IndiaCensus of Micro Small \&Medium Enterprises 2006-2007: Registered Sector. New Delhi: Development Commissioner.

Ministry of MSME, Government of India. (2012). Annual Report 2011-12. New Delhi: Development commissioner.

Ministry of MSME, Government of India. (2013). Annual Report 2012-13. New Delhi: Development commissioner.

Ministry of Small Scale Industries, Government of India. (2004). Final Results: Third All India Census of Small Scale Industries 2001-2002. New Delhi: Development Commissioner.

Nagayya, D., \& Rao, T. V. (2011). Enabling small and medium enterprises target globalization. Productivity, 52(1), 67-79.

Narasaiah, P. V., \& Murthy, S. D. (2009). SSI sector in post reforms: A critical review. Monthly Commentary on Indian Economic Conditions, 69(591/3), 17-21.

Prasad, C. S. (2004). Small and Medium Enterprises in global perspective: Employment generation and WTO vision 2012. New Delhi: New century publications. ISBN 9788177080735.

Singh, A. (2009). Small scale industries in a global perspective. Productivity, 49(4), 290-296.

Singh, G., Rana, P. S., \& Singhal, C. (2009). Role of Industrialization in Economic Development in India. IME Journal, 3(1), 15-19.

Small Industries Development Bank of India. (2010). SIDBI Report on Micro, Small andMedium Enterprises Sector 2010. Lucknow: Small Industries Development Bank of India.

Tambunan, T. T. H. (2009). SMEs in Asian developing countries. New York: Palgrave Macmillan. $\mathrm{http}: / / \mathrm{dx}$. doi.org/10.1057/9780230250949

UNIDO. (1968). Industrial Estates in Europe and Middle East. New York: United Nations.

\section{Copyrights}

Copyright for this article is retained by the author(s), with first publication rights granted to the journal.

This is an open-access article distributed under the terms and conditions of the Creative Commons Attribution license (http://creativecommons.org/licenses/by/3.0/). 